ORIGINAL ARTICLE

\title{
Comparison of Academic Achievements of Public and Private Diploma Graduates at Degree Level in Public HEI (AAUCC)
}

\section{Berhanu Nigussie*}

\begin{abstract}
This study attempted to examine the academic achievements of evening degree students from private and public colleges training background, at Addis Ababa University College of Commerce (AAUCC), during 11 consecutive semesters. The specific objectives of the study were to compare the performance differences, if any, between the two groups of students; to see the conditions of dropout and academic dismissal; and to find out possible measures that may be taken by the concerned bodies.
\end{abstract}

Data for this study were collected from the Record Office of the college (AAUCC). The data of 344 public group and 89 (because the admission quota was only $20 \%$ for the private) private group students of three departments of the college (Accounting, Business Administration and Information Systems and Marketing Management) were collected and analyzed. The study used quantitative data as its major source of information even though there were some qualitative data obtained from interviews with instructors, students, and counselor.

The results of the study revealed that there were statistically significant differences between private and public groups. Except during 3 semesters of the Department of Marketing Management, the public group students performed better during all the 11 semesters of the two departments and during 8 semesters of the other department. Dropout in general and dropout due to academic reason were also higher for private group students. Moreover, the interviewees highly stressed that private and public institutions should work together to maintain higher education system attuned to the public good. Ideas were further discussed and implications about quality in higher education institutions were underlined.

\footnotetext{
* Department of Psychology Jimma University, Jimma Ethiopia E-mail: brexnigussie@yahoo.com
} 


\section{INTRODUCTION}

\section{Background of the Problem}

Access to higher education in Ethiopia like in other African countries has been restricted to very few public higher education institutions until the launching of Education and Training Policy in 1994. However, today numerous private higher education institutions are operating and playing the role of complementing the public higher education institutions (Damtew, 2005). Hence, expanding and nurturing both public and private tertiary level education is of paramount importance.

Together with the expansion of higher education institutions, the issue of quality must be addressed properly. A failure to address quality of education at the tertiary level could be a hindrance to the overall development attempts.

Focusing on quality education in Ethiopia, Daniel (2005) stated that opportunities for access to higher education have shown marked increase following the expansion of public and private higher education institutions. On the other hand, there is equally valid and widely shared concern that the higher education expansion in the country appears primarily quantitative and there is a serious question concerning quality. There are serious challenges in meeting minimum standards for quality education. Providing adequate number of qualified staff, sufficient library, classroom facilities, etc are some of the challenges that need to be successfully addressed if quality is to be maintained.

He stressed that the government of Ethiopia and the higher education management should pose for at least a brief period and address concerns pertaining to quality in higher education in both public and private higher education institutions.

\section{Statement of the Problem}

Among higher education institutions in Ethiopia, Addis Ababa University is one of the oldest public institutions known to provide higher education for evening learners who are unable to continue their education in the regular program. And of course, Addis Ababa University College of Commerce (AAUCC) has also been contributing a lot in this regard. This institution could play a significant role in alleviating shortage of skilled human resource in various fields. The college has increased learning opportunities for evening learners. And, most of these students come from public and private colleges training background.

In most cases, those who graduated from private higher education institutions are the ones who could not join public higher education institutions where they could have academic and other services free of charge or with relatively lesser payment. Moreover, those students who dropout from public institutions and few students of well to do families, who do not want to continue their education in universities or colleges far from their home, have the chance to join private colleges.

Some educators say the more that private institutions are made available as an alternative, the more efficiently the educational system as a whole will perform. They also argued and concluded that there is very little difference between public institutions and their private counterparts. Still others argued that public institution students outperform the private ones.

These issues aroused the present researcher's interest and raised questions 
for which as yet there are no answers. So, it would be interesting to compare the academic achievements of the two groups (public and private colleges training background students) and see if they had similar academic achievements in each selected department, at AAUCC.

\section{Objectives of the study}

Based on the statement of the problem, the general objective of the study is to compare the academic achievements of evening degree students (from public and private colleges training background) of Addis Ababa University College of Commerce.

More specifically, the objectives of this research are:

1. To see whether or not the mean academic achievements of degree students from public and private colleges training background at AAUCC differ significantly.

2. To see whether the rates of drop out and academic dismissal were the same in both institutions- public and private?

3. To investigate possible factors contributing to poor academic achievements, if any, of a group (private or public colleges training background students).

4. To find out possible measures that may be taken to rectify the situation.

\section{Significance of the Study}

Accordingly, the findings of the study may serve the following major practical purposes.

1. It may serve as an additional information source and document base in the process of managing public and private higher education institutions and evening education in higher education institutions.

2. It may contribute to the improvement of public and private higher education and evening education at the higher education institutions in general and Addis Ababa University college of commerce in particular.

3. It may contribute to the efforts made to strengthen the quality of education in public and private higher education institutions

4. It may stimulate prospective researchers to conduct further research on this area and to address those areas that remain untouched or inadequately treated. And to make them realize that the previous studies have investigated only some aspects of the issue and it was treated in breadth than depth.

\section{METHODS OF THE RESEARCH}

In order to secure reliable data from all possible sources in a confidential manner, appropriate method of investigation is imperative. The study site, sample, data collection instruments, procedures of data collection and methods of data analysis used in this study are discussed here under.

\section{Study site}

The study was done in Addis Ababa. Addis Ababa has many private and public higher education institutions (HEIs). Addis Ababa University College of Commerce was selected for the study.

\section{Sample}

From the existing six departments at AAUCC which were open for evening degree students, Accounting, Marketing Management and Business Administration and Information Systems were purposely selected. The reason was that students from both public and private colleges training background were found and the numbers were reasonable for comparison purposes in the selected departments, though the quota of admission for public was $80 \%$ and $20 \%$ for the private one (that is why the number is very less for the private group). 
In this study, the academic records of a total of 433 (136 Females and 297 Males) students (without considering dropouts in the first semester of the year 2003/04) who joined the three departments of Addis Ababa University College of Commerce (AAUCC) during that academic year were documented. From these students, $344(79.45 \%)$ of them had public colleges training background and the other 89 (20.55\%) were from private colleges training background.

\section{Instruments of Data Gathering}

The present research heavily relied on the analysis of the academic records of the students. In addition, an interview guide was used to interview students, counselor and instructors to get information on factors contributing to poor academic performances of a group and possible measures to be taken by the concerned bodies.

In other words, interviews were conducted after the researcher had made the analysis of the academic records of the students to find out possible reasons and measures for the less academic performances and dropout of students from public and private colleges at AAUCC.

It has been evidenced that record of students' achievement over a long period is likely to give a more accurate picture of the ability of students (Vale, 1995). Thus, Cumulative Grade Point Averages (CGPA) were collected from the registrar's office of the college.

In addition to students' academic records, unstructured interviews were used. It was used because it enabled participants to explain their views without any restriction. These interviews were conducted with three experienced instructors (one from each department), one counselor and six dropout students (two from each department, and three from public and the other three from private colleges) who have currently been attending their dropped out education.

Before the beginning of the interview process, ethical issues were discussed. For example, permission was obtained to record the interview and promise was made about the confidentiality of the interviewees’ responses.

\section{Procedures of data collection}

The records of 433 students were colleted from the Registrar Office of AAUCC. Data collection sheets were prepared in which case the rows represented data of each student and 15 columns represented the variables for each student. The variables were type of institution (private or public), ESLCE GPA, diploma CGPA, semesters 1to11GPAs and CGPAs. A total of 13 data collectors was oriented and deployed in the data collection.

Data were collected starting from 2003/04 academic year semester 1 until 2006/07 academic year, which was for 11 consecutive semesters. Because complete data (from entry to graduation) were collected, this study can really speak something about the research problem. Moreover, data of students who withdrew or academically dismissed were included so that they could give full picture of the entrants of the academic year 2003/04. Finally, the data were entered into the SPSS version 15 and made ready for analysis.

\section{Methods of Data Analysis}

Both qualitative and quantitative data analysis methods were used in this study. To analyze the collected data, such descriptive statistics as means, standard deviations and percentages were used. Chi- 
square test ( $\chi^{2}$.test) for significance of proportional difference was also used. Largely independent groups t-test were used to observe if there were mean GPA differences between students with public and private colleges training background.

Table 1: Mean GPAS of Students from public and private colleges in the Department of Accounting, AAUCC(2003/04-2006/07 AY at Degree Level.

\begin{tabular}{|c|c|c|c|c|c|c|c|c|}
\hline & \multirow[b]{2}{*}{$\begin{array}{c}\text { Types } \\
\text { of Institution }\end{array}$} & \multicolumn{7}{|c|}{ t-test for equality of means } \\
\hline & & $\mathrm{N}$ & Mean & SD & $\begin{array}{l}\text { Std. } \\
\text { Error } \\
\text { mean }\end{array}$ & $\mathrm{t}$ & $\mathrm{df}$ & $\begin{array}{l}\text { Sig. (2- } \\
\text { tailed) }\end{array}$ \\
\hline \multirow[t]{2}{*}{ Dip_CGPA } & Public & 167 & 2.5766 & .4088 & .0316 & -23.581 & 223 & .000 \\
\hline & Private & 58 & 3.3947 & .3526 & .0463 & & & \\
\hline \multirow[t]{2}{*}{ Sem1_GPA } & Public & 167 & 2.8228 & .4583 & .0356 & 7.211 & 223 & .000 \\
\hline & Private & 58 & 2.2960 & .5356 & .0703 & & & \\
\hline \multirow[t]{2}{*}{ Sem2_GPA } & Public & 167 & 2.8912 & .5517 & .0427 & 6.907 & 223 & .000 \\
\hline & Private & 58 & 2.2234 & .8293 & .1089 & & & \\
\hline \multirow[t]{2}{*}{ Sem3_GPA } & Public & 167 & 2.8683 & .7900 & .0611 & 4.414 & 217 & .000 \\
\hline & Private & 52 & 2.3462 & .5734 & .0795 & & & \\
\hline \multirow[t]{2}{*}{ Sem4_GPA } & Public & 166 & 2.7316 & .7183 & .0558 & 6.086 & 216 & .000 \\
\hline & Private & 52 & 2.0290 & .7518 & .1043 & & & \\
\hline \multirow[t]{2}{*}{ Sem5_GPA } & Public & 166 & 2.7546 & .7428 & .0578 & 4.069 & 212 & .000 \\
\hline & Private & 49 & 2.2749 & .6589 & .0941 & & & \\
\hline \multirow[t]{2}{*}{ Sem6_GPA } & Public & 163 & 3.0287 & .7473 & .585 & 3.415 & 210 & .000 \\
\hline & Private & 49 & 2.602 & .8290 & .1184 & & & \\
\hline \multirow[t]{2}{*}{ Sem7_GPA } & Public & 161 & 2.8439 & .5928 & .467 & 4.617 & 206 & .000 \\
\hline & Private & 47 & 2.411 & .4573 & .067 & & & \\
\hline \multirow[t]{2}{*}{ Sem8_GPA } & Public & 160 & 2.8402 & .6545 & .0517 & 5.167 & 205 & .000 \\
\hline & Private & 47 & 2.2913 & .5886 & .0859 & & & \\
\hline \multirow[t]{2}{*}{ Sem9_GPA } & Public & 160 & 2.7156 & .7325 & .0579 & 5.015 & 204 & .000 \\
\hline & Private & 46 & 2.0978 & .7499 & .1106 & & & \\
\hline \multirow[t]{2}{*}{ Sem10_GPA } & Public & 159 & 2.8545 & .6736 & .0534 & 5.696 & 201 & .000 \\
\hline & Private & 44 & 2.1625 & .8430 & .1271 & & & \\
\hline \multirow[t]{2}{*}{ Sem11_GPA } & Public & 158 & 2.7739 & .5401 & .0430 & 4.064 & 196 & .000 \\
\hline & Private & 40 & 2.4003 & .4260 & .0674 & & & \\
\hline \multirow[t]{2}{*}{ CGPA } & Public & 158 & 2.7682 & .7304 & .0581 & 4.544 & 196 & .000 \\
\hline & Private & 40 & 2.157 & .8675 & .1372 & & & \\
\hline
\end{tabular}

N.B. The quota of admission for public was $80 \%$ and $20 \%$ for the private one (that is why the number is very less for the private group).

\section{RESULTS}

This section presents the results of statistical analysis carried out to answer the basic questions raised in the study. In addition, it includes interview responses from instructors, counselor and students of AAUCC. 


\section{Academic Achievements of the students}

This study defines academic achievement by GPA. Several researchers have also used grade point average (GPA) as their definition of academic achievement. Most importantly, there are research evidences to support that teacher evaluations of their students are sufficiently valid and reliable criteria of students' academic achievements.

\section{Academic achievements of students in the Department of accounting, AAUCC Diploma Mean Cumulative GPAs}

The results in table 1 indicate that the mean diploma cumulative GPA of students from private colleges in the department of accounting was $3.3947(\mathrm{M}=3.3947, \mathrm{SD}=$ 0.3526), while the mean diploma cumulative GPA of students from public colleges in the same department was $2.5766(\mathrm{M}=2.5766, \mathrm{SD}=4088)$. Independent groups t-test showed that the mean difference between these two groups was statistically significant: $t$ (223) =13.581, $\mathrm{P}=0.00$. These results indicated that students from private colleges joined the department of accounting, AAUCC, with higher diploma mean cumulative GPA, than those from public colleges.

\section{All Semesters Mean GPAs}

As can be clearly seen from Table 1 above, the mean values indicate that students from public colleges in the Department of Accounting, AAUCC, performed better during all the eleven semesters than those from private colleges.

\section{Mean Cumulative GPAs}

Results indicate that mean cumulative GPA of students from private colleges in the Department of Accounting, AAUCC, was $2.157(\mathrm{M}=2.157, \mathrm{SD}=0.8675)$, while the mean cumulative GPA of students from public colleges was 2.7682 ( $M=2.7682$, $\mathrm{SD}=0.7304)$. Independent groups t-test showed that difference between these two groups was significant: t (196) $=4.544$, $\mathrm{P}=0.00$. These results indicate that in the Department of Accounting, students from private colleges performed less than those from public colleges in their overall academic achievements.

\section{Academic Achievements of Students in the Department of Business Administration and Information Systems, AAUCC}

\section{Diploma Mean Cumulative GPAs}

Results presented in Table 2 indicate that diploma mean cumulative GPA of students from public colleges in the Department of Business Administration and Information Systems, AAUCC, was 3.0182 ( $\mathrm{M}=3.0182$, $\mathrm{SD}=0.4996)$, where as the diploma mean cumulative GPA of students from private colleges in the same department was $3.3288(\mathrm{M}=3.3288, \mathrm{SD}=0.4422)$. The t-test for independent groups revealed that the difference between these two groups was significant: $\mathrm{t}(115)=-2.343, \mathrm{p}=0.021$. These results indicated that in the Department of Business Administration and Information Systems, students from public colleges joined the department with less diploma mean cumulative GPA than those from private colleges.

\section{All Semesters Mean GPAs}

The analysis in Table 2 shows that students from private colleges performed less than students from public colleges during all semesters in the Department of Business Administration and Information Systems, AAUCC. 
Table 2: Mean GPAs of Students from public and private colleges in the department of Business administration and information system, AAUC (2003/04-2006/07 AY).

\begin{tabular}{|c|c|c|c|c|c|c|c|c|}
\hline \multirow{2}{*}{\multicolumn{2}{|c|}{$\begin{array}{c}\text { Types } \\
\text { of Institution }\end{array}$}} & \multicolumn{7}{|c|}{ t-test for equality of means } \\
\hline & & $\mathrm{N}$ & Mean & SD & $\begin{array}{l}\text { Std. } \\
\text { Error } \\
\text { mean }\end{array}$ & $\mathrm{t}$ & $\mathrm{df}$ & $\begin{array}{l}\text { Sig. (2- } \\
\text { tailed) }\end{array}$ \\
\hline \multirow[t]{2}{*}{ Dip_CGPA } & Public & 101 & 3.082 & .4996 & .0497 & $\begin{array}{l}- \\
2.343 \\
\end{array}$ & 115 & .021 \\
\hline & Private & 16 & 3.3288 & .4422 & .1105 & & & \\
\hline \multirow[t]{2}{*}{ Sem1_GPA } & Public & 101 & 3.1752 & .5003 & .0498 & 6.148 & 115 & .000 \\
\hline & Private & 16 & 2.3463 & .5068 & .1267 & & & \\
\hline \multirow[t]{2}{*}{ Sem2_GPA } & Public & 101 & 2.8796 & .8169 & .0813 & 4.158 & 115 & .000 \\
\hline & Private & 16 & 1.9663 & .8134 & .2034 & & & \\
\hline \multirow[t]{2}{*}{ Sem3_GPA } & Public & 97 & 2.8325 & .7556 & .0767 & 4.312 & 110 & .000 \\
\hline & Private & 15 & 1.9200 & .8099 & .2091 & & & \\
\hline \multirow[t]{2}{*}{ Sem4_GPA } & Public & 96 & 2.8585 & .8932 & .0912 & 2.922 & 108 & .004 \\
\hline & Private & 14 & 2.1250 & .7516 & .2009 & & & \\
\hline \multirow[t]{2}{*}{ Sem5_GPA } & Public & 92 & 2.7202 & .9650 & .1006 & 3.166 & 103 & .002 \\
\hline & Private & 13 & 1.8400 & .7050 & .1955 & & & \\
\hline \multirow[t]{2}{*}{ Sem6_GPA } & Public & 85 & 2.9208 & .7419 & .0805 & 3.202 & 95 & .002 \\
\hline & Private & 12 & 2.2083 & .5418 & .1564 & & & \\
\hline \multirow[t]{2}{*}{ Sem7_GPA } & Public & 85 & 2.8187 & .6834 & .0741 & 4.933 & 95 & .000 \\
\hline & Private & 12 & 1.6942 & 1.0732 & .3098 & & & \\
\hline \multirow[t]{2}{*}{ Sem8_GPA } & Public & 83 & 2.7595 & .6406 & .0703 & 2.896 & 90 & .005 \\
\hline & Private & 9 & 2.1278 & .3748 & .1249 & & & \\
\hline \multirow[t]{2}{*}{ Sem9_GPA } & Public & 83 & 2.6386 & 6998 & .0768 & 2.935 & 90 & .004 \\
\hline & Private & 9 & 1.9444 & .3005 & .1002 & & & \\
\hline \multirow[t]{2}{*}{$\begin{array}{l}\text { Sem10_GP } \\
\text { A }\end{array}$} & Public & 83 & 2.7673 & .5641 & .0619 & 2.409 & 90 & .018 \\
\hline & Private & 9 & 2.3033 & .3591 & .1197 & & & \\
\hline \multirow{2}{*}{$\begin{array}{l}\text { Sem11_GP } \\
\text { A }\end{array}$} & Public & 83 & 2.8048 & .5444 & .0598 & 2.903 & 90 & .005 \\
\hline & Private & 9 & 2.2667 & .3192 & .1064 & & & \\
\hline \multirow[t]{2}{*}{ CGPA } & Public & 83 & 2.7201 & .8618 & .0946 & 3.805 & 90 & .000 \\
\hline & Private & 9 & 1.5278 & 1.1646 & .3133 & 3.805 & 90 & .000 \\
\hline
\end{tabular}

N.B. The quota of admission for public was $80 \%$ and $20 \%$ for the private one (that is why the number is very less for the private group).

\section{Mean Cumulative GPAs}

Further results indicated that the mean cumulative GPA of students from private colleges in the Department of Business Administration and Information Systems, AAUCC, was $1.5278(\mathrm{M}=1.5278$, $\mathrm{SD}=1.1646$ ), while the mean cumulative GPA of students from public colleges in the same department was 2.7201 (M= $2.7201, \mathrm{SD}=0.8618$ ). Independent groups t-test indicated that the difference between these two groups was significant: $t$ (90) $=3.805, \mathrm{P}=0.00$. These results indicated that in the Department of Business Administration and Information systems, 
students from private colleges performed less, in their overall academic achievements of the program, than those from public colleges.

\section{Academic Achievements of Students in the Department of Marketing Management, AAUCC}

\section{Diploma Mean Cumulative GPAs}

The results of this study also showed that the diploma mean cumulative GPA of students from private colleges in the Department of Marketing Management, AAUCC, was 3.0373(M=3.0373, $\mathrm{SD}=0.4506$ ), while the diploma mean cumulative GPA of students from public colleges in the same department was $2.6297 \quad(\mathrm{M}=2.6297, \quad \mathrm{SD}=0.411)$. Independent groups t-test showed that the difference between these two groups was significant: $t$ (89) $=-3.455, \mathrm{P}=0.001$. These results indicated that in the Department of Marketing Management, students from private colleges joined the department with better diploma mean cumulative GPA than those from public colleges.

\section{Patterns of Academic Achievements of the Two Groups (Public and Private) in the Department of Marketing Management}

As can be observed from Table 3 above, students from public colleges performed better than those from private colleges during all semesters except during semesters five, seven and eight. During these three semesters (5,7and 8), students of the two groups (public and private) in the Department of Marketing Management did not show statistically significant mean differences in their academic achievements.

\section{Mean Cumulative GPAs}

The results of this study illustrated that the mean cumulative GPA of students from public colleges in the Department of Marketing Management, AAUCC, was 2.5186( $\mathrm{M}=2.5186, \mathrm{SD}=0.8184)$, while the mean cumulative GPA of students from private colleges in the same department was $1.6422(\mathrm{M}=1.6422, \mathrm{SD}=1.2791)$. The t-test for independent groups indicated that the difference between these two groups was significant: $t(72)=2.795, P=0.007$. These results indicated that in the Department of Marketing Management, students from public colleges performed better than their private counterparts, while comparing the mean cumulative GPAs of the two groups.

\section{Conditions of Dropout of Evening Degree Students (2003/04 Entrants) from Public and Private Colleges in the Three Selected Departments of AAUCC}

Tables 4 and 5 below summarize the comparison of dropout students from public and private colleges in each selected department of AAUCC and the two groups in the three departments in general. Percentage was used for this purpose. 
Table 3; Mean GPAs of Students From Public and Private Colleges in the Department of Marketing Management, AAUCC (2003/04-2006/07AY) at Degree Level.

\begin{tabular}{|c|c|c|c|c|c|c|c|c|}
\hline & \multirow[b]{2}{*}{$\begin{array}{c}\text { Types } \\
\text { Institution }\end{array}$} & \multirow[b]{2}{*}{$\mathrm{N}$} & \multirow[b]{2}{*}{ Mean } & \multicolumn{4}{|c|}{ t-test for equality of means } & \multirow[b]{2}{*}{$\begin{array}{l}\text { Sig. } \\
(2- \\
\text { tailed } \\
\text { ) } \\
\end{array}$} \\
\hline & & & & SD & $\begin{array}{l}\text { Std. } \\
\text { Error } \\
\text { mean }\end{array}$ & $\mathrm{t}$ & $\mathrm{df}$ & \\
\hline \multirow[t]{2}{*}{ Dip_CGPA } & Public & 76 & 2.6297 & .411 & .0472 & -3.455 & 89 & .001 \\
\hline & Private & 15 & 3.0373 & .4506 & .1163 & & & \\
\hline \multirow[t]{2}{*}{ Sem1_GPA } & Public & 76 & 2.8662 & .5681 & .0652 & 4.274 & 89 & .000 \\
\hline & Private & 15 & 2.1560 & .5371 & .1387 & & & \\
\hline \multirow[t]{2}{*}{ Sem2_GPA } & Public & 76 & 2.8299 & .5729 & .0657 & 5.270 & 89 & .000 \\
\hline & Private & 15 & 1.8380 & 1.0310 & .2662 & & & \\
\hline \multirow[t]{2}{*}{ Sem3_GPA } & Public & 76 & 2.5276 & .6424 & .0737 & 3.335 & 86 & .001 \\
\hline & Private & 12 & 1.8333 & .8349 & .2410 & & & \\
\hline \multirow[t]{2}{*}{ Sem4_GPA } & Public & 76 & 2.4874 & .8306 & .0953 & 2.331 & 85 & .022 \\
\hline & Private & 11 & 1.8282 & 1.1656 & .3514 & & & \\
\hline \multirow[t]{2}{*}{ Sem5_GPA } & Public & 73 & 2.6538 & .7528 & .0881 & .926 & 80 & .357 \\
\hline & Private & 9 & 2.4167 & .3953 & .1318 & & & \\
\hline \multirow[t]{2}{*}{ Sem6_GPA } & Public & 70 & 2.3893 & .4813 & .0575 & 2.915 & 77 & .005 \\
\hline & Private & 9 & 1.8333 & .7071 & .2357 & & & \\
\hline \multirow[t]{2}{*}{ Sem7_GPA } & Public & 70 & 2.3287 & .6606 & .0790 & .924 & 77 & .358 \\
\hline & Private & 9 & 2.0278 & .4826 & .1609 & & & \\
\hline \multirow[t]{2}{*}{ Sem8_GPA } & Public & 67 & 2.5899 & .5350 & .654 & 1.706 & 74 & .092 \\
\hline & Private & 9 & 2.2578 & .6475 & .2158 & & & \\
\hline \multirow[t]{2}{*}{ Sem9_GPA } & Public & 67 & 2.7991 & .8208 & .1003 & 2.272 & 74 & .026 \\
\hline & Private & 9 & 2.1111 & 1.0833 & .3611 & & & \\
\hline \multirow[t]{2}{*}{ Sem10_GPA } & Public & 66 & 2.8044 & .6613 & .0814 & 2.601 & 73 & .011 \\
\hline & Private & 9 & 2.1711 & .8545 & .2848 & & & \\
\hline \multirow[t]{2}{*}{ Sem11_GPA } & Public & 66 & 2.6883 & .6344 & .0780 & 2.240 & 73 & .028 \\
\hline & Private & 9 & 2.1900 & .5530 & .1843 & & & \\
\hline \multirow[t]{2}{*}{ CGPA } & Public & 65 & 2.5186 & .8184 & .1015 & 2.797 & 72 & .007 \\
\hline & Private & 9 & 1.6422 & 1.2791 & .4264 & & & \\
\hline
\end{tabular}

N.B. The quota of admission for public was $80 \%$ and $20 \%$ for the private one (that is why the number is very less for the private group).

Table 4: Proportions of Dropouts of the two groups (public and private at AAUCC.

\begin{tabular}{llllll}
\hline $\begin{array}{l}\text { Types of } \\
\text { Institution }\end{array}$ & $\mathbf{N}$ & Dropouts & Percent & $\begin{array}{l}\text { Chi-square } \\
\text { test }\end{array}$ & $\begin{array}{l}\text { Sig. } \\
\text { sided) }\end{array}$ \\
\hline Public & 344 & 56 & 16.28 & $\chi^{2}=36.840$ & $\mathrm{P}=.000$ \\
\hline Private & 89 & 42 & 47.19 & & \\
\hline
\end{tabular}


In Table 4 above, comparison of the percentages of dropouts of the two groups showed that the dropout rate of private students (47.19\%) was about three times (2.90 times) that of the public one (16.28).

The chi-square result obtained
( $\chi^{2}=36.840, \mathrm{p}_{=} .000$ ) confirmed that there was statistically significant difference between the proportions of public and private dropouts

Table 5: Proportions of Academically Dismissed Students out of the Dropouts at AAUCC

\begin{tabular}{llllll}
\hline $\begin{array}{l}\text { Types of } \\
\text { Institution }\end{array}$ & Dropouts & $\begin{array}{l}\text { Academic } \\
\text { dismissal }\end{array}$ & Percent & $\begin{array}{l}\text { Chi-square } \\
\text { test }\end{array}$ & $\begin{array}{l}\text { Sig. } \\
\text { sided) }\end{array}$ \\
\hline Public & 56 & 11 & 19.64 & $\chi^{2}=4.134$ & $\mathrm{P}=.042$ \\
\hline Private & 42 & 17 & 40.48 & & \\
\hline
\end{tabular}

Students might discontinue their education for academic and non-academic reasons. Hence, Table 5 illustrates percentages of dropped out students who were academically dismissed.

It indicated, in all the three departments, that dropout due to academic reason was higher for private group than for the public one. In other words, dropout students who were academically dismissed were higher in private group (40.48\%)-about two times (2.06 times) that of the public group (19.64\%). As indicated, the result of chisquare test for significance of proportional difference, concerning students' academic dismissal, between the two groups was found to be significant (See Table 5).

This study and most local studies have indicated dropout as mostly due to academic dismissals. Poor academic performance is one of the most often cited correlate of dropout.

Possible Reasons and Measures for Poor Academic Performances and Dropout of the Students

Based on the interviews conducted with instructors, students and counselor, attempts were made to examine and find out possible reasons and measures for the less academic performances and dropout of the students. The following points are the interview results.

Participant instructors think that there is academic performance difference between students from public and private colleges training background. Many perceived students from private colleges as academically less competent. Except in certain very few circumstances, though they did not know to which group students belonged, some participant instructors said that more students from private colleges dropped out from the program for academic reasons.

Many interviewees were concerned about the private institutions use of relatively more part-time staff who awarded more A's and B's than their full-time counterparts. Part-time instructors gave inflated grades perhaps to continue their part-time employment and satisfy their overriding financial concerns, they justified.

Most interviewees explained that the quality of education is partly determined by the success of students in the academic world. To enhance the roles of education in 
Ethiopia, expanding and nurturing-giving due attention to quality of education- both public and private higher education institutions are of paramount importance, as stressed by the interviewees. Many believed that numerous private higher education institutions are operating and playing the role of complementing the public higher education institutions.

Finally, they suggested that private institutions, in addition to work for profit, could play practically significant roles in producing competent and confident citizens, minimizing the above commented problems and other possible limitations. In doing so, they added that the two groups (private and public) could work hand in hand to contribute significantly to the country’s development.

\section{DISCUSSION}

This section discusses the major findings of the study. That is, the results reported in part three are interpreted and discussed here. The findings of the present study and the available related literature are linked in the discussion.

The results, obtained by using independent groups t-test, showed that the mean CGPA difference between public and private groups was statistically significant, in each department considered. These results indicated that students from private colleges joined all the three departments of AAUCC with better diploma mean CGPAs than those from public colleges. Surprisingly, the situations were reversed during all the eleven semesters. Students from public group outperformed those from private group in the three departments.

When GPAs of public and private groups were assessed for 11 semesters since 2003/04, in most cases, the public group students were surpassing the students from private colleges. It was only in three semesters of the Department of Marketing Management that the two groups achieved similar results.

Moreover, dropout in general and academic dismissal in particular was higher for private group than for the public one, in all the three departments of AAUCC. Poor academic performance is one of the most often cited correlate of dropout (Asmerom et al, 1989).

The possible reasons for relatively less academic performances and dropout of the students from private colleges could be limitations in educational resources, students' award of generous grades to study in private institutions and teachers' very high work load in private colleges. Weekly work load for instructors in public colleges were 6 to 18 periods; while for private college instructors, the minimum workload was 11 to36 periods per week. Thus, the over burden of private colleges instructors might harm their moral, motivation for teaching and quality of the teaching learning process (Teshome, 2005).

Students from private colleges explained that the comparison had been among themselves and relatively easy in private colleges; but the competition was tough with students from public colleges, at AAUCC. Inconvenient teaching-learning atmosphere, timing of the evening program, personal and occupational problems were also some of the reasons they mentioned.

Moreover, many interviewees explained that private colleges use relatively more part-time instructors who awarded more A's and B's than their full-time counterparts. They justified that those parttimers awarded generous grades perhaps to continue their part-time employment and 
satisfy their financial concerns. Supporting this, Rajagopal and Lin (1996) found inflationary tendencies in part-timer taught sections, which was frequent in private than in public higher education institutions.

They further explained that part-time staff has certain deprofessionalized academic functions. The fact that they work under different conditions and with different status types may suggest that testing irregularities and abuse of grading standards may occur. Regarding this, many researchers (Amanuel, et al, 2004; Teshome, 2005; Williams, 1985) found consistent results with the present researcher.

As possible measures, many interviewees suggested the harmonious working together of private and public higher education institutions, if they are to bring change and contribute their parts to the country's development. Many stressed on the contributions the private institutions so far made to the citizens of the country.

Further more, they suggested the private institutions to go beyond their present status (especially in producing academically competent professionals) by intensively working on their possible limitations and further enriching their strengths, to rectify the existing situations.

\section{CONCLUSIONS}

In light of the major findings of the study, the following conclusions could be drawn: 1. Independent groups t-test results showed that the diploma mean CGPA differences between public and private groups were statistically significant (in favor of the private group) in all the three departments of AAUCC. These results indicated that students from private colleges joined Addis Ababa University College of Commerce with better diploma mean CGPAs than those from public colleges. However, the situations were reversed during all the eleven semesters-students from public group surpassed those from private group, in all the three departments.

2. The rate of dropout was higher for private group than for the public one, in all the three departments. Furthermore, the percentage of those dropout students who were academically dismissed was higher for private group than for public group. The chi-square test confirmed the proportional differences between the two groups, in both dropout and academic dismissal. This and most local studies have indicated dropout as mostly due to academic dismissals.

3. Teachers' higher work load, lack of sufficient educational resources, generous award of grades for students (in private colleges), timing of evening program, personal and occupational problems could be some possible reasons for poor academic performances and dropout of most students. Challenging academic competition for private group students and private colleges' use of relatively more part-timers (who awarded generous grades to satisfy their own personal interests) were also possible reasons explained by most interviewees.

4. Some suggested possible measures or corrective actions were:

$>$ Conducive working environment for both public and private higher education institutions to work together to maintain higher education system attuned to the public good.

$>$ Government's responsibility to support private institutions as they could reduce unemployment, open job opportunities for many citizens, and most importantly, contribute significantly to the country's development. 
$>$ Government's responsibility to regulate both public and private institutions to provide quality education supported with research.

$>$ Private institutions' initiatives to work on their possible limitations and further enrich their strengths, to help them produce academically, psychologically and socially competent citizens.

5. At the end, it could be said that problems and drawbacks in both public and private higher education institutions are threats to the quality of education in the country.

\section{Recommendations}

Based on the findings of the study, the following recommendations are given.

1. Most students from private colleges who joined AAUCC with better diploma CGPAs could not score better in the college. As a result, the Academic Commission of AAUCC could include Entrance Examinations as selection criteria, the predictive validity of which many researchers proved.

2. Provision of guidance and counseling services, by professional counselor, is needed for evening students. So, administrative bodies of AAUCC should think of this issue critically, for the benefits of their students.

3. Together with expanding higher education institutions, the Ministry of Education should carefully supervise their works to address the quality of education in the country. Because through quality programs, students would secure jobs and are valued highly by employers.

3. Public and private higher education institutions should work together to provide quality education and contribute their parts significantly to the development of the country.

4. To draw a more general picture of the problem, further study is needed.

\section{ACKNOWLEDGEMENT}

I would like to take the opportunity to thank members of AAUCC Registrar Office who gave me access to the necessary documents. Moreover, my utmost appreciation goes to the editors of this article for their insightful and constructive comments. Their useful suggestions highly contributed to the improvement of the article.

\section{REFERENCES}

Amanuel Gebru (2004). Differences in Grading Practices of Part-time and Fulltime Faculty: A Departmental study at AAU. Journal of Development Research 26(2):1-26.

Asmerom Kidane, Lakew Woldetekle, Mekonnen Yimer and Yosuf Omar Abdi.(1989).Students Dropout from Institutions of Higher Learning in Ethiopia: Magnitude, Causes and Cures. The Ethiopian Journal of Education, $X$ (2), 1-21.

Damtew Teferra (2005). Ethiopian Higher Education: Nurturing Quality Striving for Excellence. Proceeding of Third National Conference on Private Higher Education in Ethiopian St. Mary's University College: Unpublished

Daniel Desta (2005). An Overview of Challenges and Opportunities of the Higher Education Expansion in Ethiopia. Summary of the proceedings of the National Conference Held in the School of Graduate studies, Addis Ababa University. Institute of Educational Research. 
FDRE (2003). Proclamation No 351/2003; Higher Education Proclamation: Addis Ababa: FDRE.

Jackson, E. (1986). A Comparative Study of the Effectiveness of Adjunct Faculty in the Business Division at Fayetteville Technical Institute: unpublished PH.D Dissertation, University of Nova, USA.

MOE (1994). Education and Training Policy, Addis Ababa, EMPDA.

Rajagopal, I. and Lin, Z. (1996). Hidden Careerists in Canadian Universities. Higher Education, 32,3:247-66.
Teshome Seifu (2005). A Comparative Study of Teacher Training for Primary School in Public and Private Teacher Training Colleges in Oromia. Unpublished MA thesis. AAU.

Vale, T. (1995). Meaningful Assessments: Manageable and Cooperative Process.Boston: Merrill.

Williams, J.M. (1985). A Study of Professional Development Practices for Part time Instructors at Selected League for Innovation Community. Colleges. Laguna Hills: League for Innovation in Community Colleges. 